\title{
THE ELECTION PROCESS OF THE REGIONAL REPRESENTATIVES TO THE PARLIAMENT OF THE DEMOCRATIC REPUBLIC OF AZERBAIJAN
}

\section{ВИБОРЧИЙ ПРОЦЕС РЕГІОНАЛЬНИХ ПРЕДСТАВНИКІВ У ПАРЛАМЕНТ АЗЕРБАЙДЖАНСЬКОЇ ДЕМОКРАТИЧНОЇ РЕСПУБЛІКИ}

\author{
Malikli Nurlana, \\ PhD Student \\ of the Lankaran State University
}

The mine goal of this article is to investigate the history of the creation of the Democratic Republic of Azerbaijan parliament, laws on parliamentary elections, and the regional election process in parliament. In addition, an analysis of the law on elections to the Azerbaijan Assembly of Enterprises. The article covers the periods of 1918-1920. The presented article analyzes historical processes, carefully studied and studied the process of elections of regional representatives to the Parliament of the Democratic Republic of Azerbaijan. Realities are reflected in an objective approach. A comparative historical study of the election of regional representatives was carried out in the context of the creation of the parliament of the Democratic Republic of Azerbaijan and the holding of parliamentary elections. The scientific novelty of the article is to summarize the actions of the parliament of the first democratic republic of the Muslim East. Here, attention is drawn to the fact that before the formation of the parliament, the National Assembly, in which the highest executive power, transferred its powers to the legislative body and announced the termination of its activities. It is noted that the Declaration of Independence of Azerbaijan made the Republic of Azerbaijan a democratic state. It is from this point of view that attention is drawn to the fact that the government of the Azerbaijan Democratic Republic had to complete the formation of institutions capable of creating a solid legislative base in a short time. In conclusion, it is noted that the Azerbaijani parliament has consistently created the legislative framework necessary for the recognition of the young republic in the world and for its legitimacy very quickly. It is emphasized that the law on parliament deserves praise as a political and legal document that serves as the legal basis for holding democratic elections.

Key words: Azerbaijan Democratic Republic, parliament, region, county, parliamentarians.

Мета статті - дослідити історію створення парламенту АДР, закони про вибори парламенту і регіональний виборчий процес у парламенті. Крім того, здійснити аналіз закону про вибори до Азербайджанської асамблеї підприємств. Стаття охоплює період 1918-1920 рр. У представленій статті аналізуються історичні процеси, ретельно досліджений і вивчений процес виборів регіональних представників у Парламент Демократичної Республіки Азербайджан. Реалії відображені і в об'єктивному підході. Проведено порівняльно-історичне дослідження виборів periональних представників у контексті створення парламенту Демократичної Республіки Азербайджан і проведення парламентських виборів. Відзначається, що законодавча влада - правова основа створення тимчасового парламенту Азербайджанської Демократичної Республіки - була підтверджена законом «Про заснування парламенту Азербайджанської Демократичної Республіки», прийнятим Національними Зборами Азербайджану 20 листопада 1918. Науковою новизною статті $€$ підведення підсумків діяльності парламенту першої демократичної республіки мусульманського Сходу. Звертається увага на те, що до формування парламенту Національні збори, яким вища виконавча влада передала свої повноваження законодавчого органу, оголосили про припинення своєї діяльності. Відзначається, що Декларація незалежності Азербайджану зробила Азербайджанську Республіку демократичною державою. Саме із цієї точки зору звертається увага на те, що уряду Азербайджанської Демократичної Республіки довелося завершити формування інститутів, здатних у короткі терміни створити міцну законодавчу базу. Відзначається, що парламент Азербайджану послідовно створив законодавчу базу, необхідну для визнання молодої республіки у світі і для ії легітимності, дуже швидко. Підкреслюється, що закон про парламент заслуговує похвали як політико-правовий документ, який служить правовою основою для проведення демократичних виборів.

Ключові слова: Азербайджанська Демократична Республіка, парламент, регіон, повіт, парламентарії.

Introduction. On May 28, 1918, with the Declaration of Independence, the National Assembly of Azerbaijan announced to the world that the independent Democratic Republic of Azerbaijan was established. According to the last article of the Declaration of Independence, it was stated that the National Assembly was at the head of all Azerbaijan, and that the provisional government was responsible before the meeting of the Azerbaijan Assembly of Enterprises. The organization of the activity of the Democratic Republic of Azerbaijan and its recognition by the world states was a necessity of the time [1]. On November 20, 1918, 20 the Government of the Dem- ocratic Republic of Azerbaijan, taking into account this need, was able to carry out legislative activities for the pre-election period of the Assembly of Enterprises adopts the Law on the Institution of the Parliament of Azerbaijan [2, p. 14; 3, p. 82]. This law laid the foundations for the formation of the body to exercise legislative power in the Democratic Republic of Azerbaijan from December 7, 1918 to April 27, 1920. The law states that the parliament of the Democratic Republic of Azerbaijan will be established in the 120 member and will function until the Azerbaijan Assembly of Enterprises is convened. The number of members of the National Assembly of Azerbaijan, rep- 
resented by the South Caucasus Seismic Council, was expanded by 44 members, with 14 members previously elected to the Russian Assembly of Enterprises by four different political groups in the South Caucasus, pre-existing Muslim committees intended to form minority nations among themselves and, finally, with representatives from the trade and industrial union with the Baku Trade Council [1;2, p. 14-15; 3 , p. $82 ; 4$, p. 36]. According to that law, it was necessary to determine 76 more than 44 predetermined members of parliament, at which point one of the 24,000 members was elected based on the demographic situation, national and religious identity of the population. At that time, according to the Caucasus calendar (the Caucasus calendar - the annual Caucasus publication of the Russian Empire from 1845 to 1916$), 2,750,000$ people lived in the territory of the Azerbaijan Democratic Republic. According to statistics, 1,900,000 were Muslims, 500,000 were Armenians, and 230,000 were Russians. According to these statistics and the Law on the Establishment of the Assembly of Azerbaijan, the right to send $80 \%$ of the Muslim population of the country, 21 Armenians, 10 Russians, 1 Germans, 1 Jews, were found. The law states that the "other minorities" living on the territory of the country are inadequate to accommodate large numbers. However, given the fact that Georgians and Poles are more numerous than other minorities, it was considered possible to send each (Georgian and Poles) delegates to the parliament $[1 ; 2$, p. $14 ; 3$, p. 81$]$. In accordance with this rule, minority peoples had to elect all their representatives and the Muslim population to send them to the Parliament, with 36 members representing them. Because, as we have already mentioned, out of 80 representatives to represent the Muslim population under the law, 44 members of the South Caucasus Seim were considered to have received direct mandate to the Parliament of the Republic of Azerbaijan. In the event of resignation, death, or otherwise indirectly leaving the Assembly, one of the 44 members who constituted the principal members of the National Assembly and received a direct mandate to the Parliament must be nominated by another party to its place $[1 ; 2$, p. $15 ; 3$, p. 82$]$.

The mine goal of this article is to investigate the history of the creation of the Democratic Republic of Azerbaijan parliament, laws on parliamentary elections, and the regional election process in parliament. In addition, an analysis of the law on elections to the Azerbaijan Assembly of Enterprises. The article covers the periods of 1918-1920.

Research methods. The presented article analyzes historical processes, carefully studied and studied the process of elections of regional representatives to the Parliament of the Democratic Republic of Azerbaijan. Realities are reflected in an objective approach. A comparative historical study of the election of regional representatives was carried out in the context of the creation of the parliament of the Democratic Republic of Azerbaijan and the holding of parliamentary elections.

The scientific novelty of the article is to summarize the actions of the parliament of the first democratic republic of the Muslim East. Here, attention is drawn to the fact that before the formation of the parliament, the National Assembly, in which the highest executive power, transferred its powers to the legislative body and announced the termination of its activities. It is noted that the Declaration of Independence of Azerbaijan made the Republic of Azerbaijan a democratic state. It is from this point of view that attention is drawn to the fact that the government of the Azerbaijan Democratic Republic had to complete the formation of institutions capable of creating a solid legislative base in a short time.

Literature review. The subject of the article is a new and unexplored area of research in Azerbaijani historiography. Therefore, when investigating the problem, the scientific literature related to the Parliament of the Democratic Republic of Azerbaijan was addressed.

The book written by Asadov Oktay, Jabrayilov Rafael "Parliament of the Republic of Azerbaijan" Parliament of the Republic of Azerbaijan was investigated in three directions - Parliament of the Democratic Republic of Azerbaijan (I Republic) (19181920), representative of the legislative body during the Soviet Socialist Republic of Azerbaijan activities (1920-1991), Parliament of the independent Republic of Azerbaijan (Presidency III (October 18, 1991). The book also includes parliamentary elections, regioanl election process, the election law of the Parliament and the Law issues on elections to the Assembly of Enterprises have been extensively investigated [6].

The article by Bakhishov Vusal "The persons representing the Nukha district in the Parliament of the Democratic Republic of Azerbaijan" examined the socio-political situation on the eve of the establishment of the Azerbaijan Democratic Republic and analyzed the composition of parliament on the basis of the Law on the Institution of Parliament of Azerbaijan adopted November 20, 1918. The article also extensively investigates the activities of the representatives of the Nukha (Sheki) district in the ADR parliament [1].

The article by Sadvayoglu Parviz "Azerbaijan Democratic Republic - the first parliamentary republic in the East" has been widely studied the history of the formation of the parliament of the Democratic Republic of Azerbaijan and its creation [5].

A three-volume book entitled "Parliamentary Reports and Comments in the Azerbaijan Newspaper" (researched, collected, translated from the Arabic alphabet to Latin, author of the preface, dictionary compiler Shirmammad Huseynov) is based on archival documents and materials of the Azerbaijan newspaper. The book also extensively explains the ADR 
Parliamentary election process and the approval of their mandates [7;8].

The article by Abbasova Gulara "Parliamentary Activities and Government Organization during theAzerbaijan Democratic Republic" examines the actions taken by the parliament in the cultural building of the Parliament and its government, and analyzes the tasks that parliament has set to strengthen its independence [10].

The article by Solmaz Tohidi - Rustamova "How the Parliament of Azerbaijan Created?", the history of the formation of the Azerbaijan Democratic Republic has been evaluated and studied in two directions: the National Council and the Baku period. The article also explores the activities of Nasib Bey Yusifbeyli and Fatali Khan Khoyski, who signed the Declaration of Independence declaring the establishment of the ADR [11].

The book on "Mammad Amin Rasulzadeh's works" (Volume IV) (researcher, collector, translator from Arabic alphabet to Latin, author of the preface, the compiler of the dictionary Shirmammad Huseynov) was included the founder of the Democratic Republic of Azerbaijan, one of the outstanding public and political figures of the XX century - Mammad Amin Rasulzadeh's works, speeches, reports and interviews published in the press from January 1917 to April 1918 [12].

A seven-volume book entitled "History of Azerbaijan"(Volume V) - the socio-political situation and the historical processes and events in this area have been extensively investigated before the establishment of the Azerbaijan Democratic Republic and the Parliament. The book also analyzes such issues as the beginning of democratic changes in the Azerbaijani society, the socio-political situation in the Azerbaijan Democratic Republic, and the struggle for the territorial integrity of the Azerbaijan Democratic Republic [13].

The article by Habil Hamidov "Socio-political review of the formation of the Azerbaijan Democratic Republic" - The main research object of the article is the process of formation of the Azerbaijan Democratic Republic. The article provides a socio-political analysis of the history of the formation and formation of ADR [14].

The article by Sevda Suleymanova "Formation of the First Democratic Azerbaijan Parliament" provides a comprehensive analysis of the history of the formation of the parliament of the Democratic Republic of Azerbaijan. The article also reflects the procedure for the election of the members of Parliament.

\section{ment}

The history of establishment of the ADR Parlia-

In October 1917, the Bolsheviks seized power in Petrograd proclaiming the Russian Soviet Socialist Federative Republic. The Bolshevik revolution in Petrogard is not welcomed in the Transcaucasia. As a result, on the 15th of November, 1917, the Tran- scaucasian Commissariat was established under the chairmanship of J.P. Geqechkorini, comprising representatives of three nations (Azerbaijan, Georgian and Armenian) living in the area [3, p. 4]. Representatives from the Transcaucasia elected to the Russian Assembly of Enterprises and unable to attend the Bolshevik Revolution on February 14, 1918, gather in Tbilisi and establish the Transcaucasian Seim, the Transcaucasian Parliament, in other words. The Muslim faction in the Transcaucasian region was represented by 44 MPs, who won more than one million Turkish-Muslim voters in Azerbaijan, as well as in the entire South Caucasus during the elections to the Russian Parliament. The Muslim faction of the Transcaucasian Seim (parliament), which was composed of people elected by the people, was, in fact, the Muslim Council of the Transcaucasia and served as the Muslim Parliament of the entire South Caucasus [4, p. 28].

It was interesting and at the same time, as it was in the State Duma, the most consistent members of the Transcaucasian Seim were the representatives of Azerbaijan in matters of common interest in the Caucasus. Exactly on their request on April 22, 1918, the Transcaucasian Seim declared independence of the South Caucasus and the Democratic Republic of Transcaucasia was established. However, the presence of acute national interests in both domestic and foreign policy did not allow the Transcaucasian Seim and the Government of the United Transcaucasian Republic to take concrete steps [4, p. 28]. In addition, internal conflicts between representatives of different ethnic groups in Seim and deficiencies in external orientation did not allow them to find common language [2, p. 4]. Representatives of all three nations operating in the Transcaucasian Seim and in their government each favored their nation's interests over the Caucasus. They did not have a common platform. On May 25, 1918, the final meeting of the Transcaucasian Seim was held. Georgia withdraws from the Caucasus Seim and declares its independence on May 26 [4, p. 28].

Following Georgia, Armenia is also preparing to declare its independence. In this context, the Muslim fraction of the Caucasus Seim also, after a comprehensive discussion, concludes that "if Georgia declares its independence, then Azerbaijan must declare its independence" $[2$, p. 5].

On May 27, the day after the demise of the Transcaucasian Seim, members of the Seim Muslim faction also held separate meetings and decided to declare independence of Azerbaijan. To this end, the Muslim part of the Caucasus region declared itself the National Council of Azerbaijan, or rather the Parliament of Azerbaijan. Thus, in fact, the first parliament of Azerbaijan was created and the first parliamentary republic was laid [4, p. 28].

All Muslim representatives are gathered in Tbilisi to declare independence and establish the first Azerbaijani government. After a thorough discussion, they 
declare themselves the National Council of Azerbaijan, deciding to take over the rule of Azerbaijan in such a difficult time. The presidium of the National Council is elected at this meeting. The presidium of the party "Musavat" byM. Hajinski, N. Yusifbeyov, H. Hasmammadov, M.Y. Jafarov, from the Muslim socialist parties Kh. Sheikh-ul-Islamov and Dr. Kh. Sultanov from the party Russian muslims of "Ittihad". By secret ballot Rasulzadeh is elected chairman of the National Council of Azerbaijan [4, p. 28].

On May 28, a meeting of the National Council of Azerbaijan chaired by Dr. Hasan bey Agayev is being held. After a long and comprehensive discussion, the National Council, with a great deal of enthusiasm, admits the Declaration of Independence of Azerbaijan on the sidelines and through the ages of joy $[1$, p. 5]. The Declaration of Independence signifies that for the first time in the Turkic-Muslim world, the most democratic governance system in Azerbaijan will be established. At the same meeting, the National Council of Azerbaijan also approved the composition of the first provisional government of the Democratic Republic of Azerbaijan, chaired by the impartial Fatali khan Khoyski. The first provisional government was in this composition [4, p. 29]:

Fatali khan Hoyski - Chairman and Minister of the Interior, Khosrov Pasha bey Sultanov - Minister of Foreign Affairs, Mammad Hasan Hajinski - Minister of Foreign Affairs, Nasib Bey Yusifbeyli - Minister of Finance and Public Education; Khalil bey Khasmammadov - Minister of Justice; Mammad Yusif Jafarov - Minister of Commerce and Industry; Akbar aga Sheikhulislamov - Minister of Agriculture and Labor; Khudadat bey Malik-Aslanov - Minister of Roads and Postal Service Camo bey Hacinski - Minister of State Control.

Thus, as a result of the freedom struggle that has persisted for over 100 years in Northern Azerbaijan, the ancient state traditions of the people in the northern lands of Azerbaijan have been revived again, and this time in the form of a parliamentary republic. The great historical service of the republic's officials was that they restored the sacred "Azerbaijan" stamp, which was forgotten in the north of the country after the Russian occupation. The newly revived state of the people entered the political arena of the world under the name of "Azerbaijan". Republican figures have also laid the foundations of parliamentary culture in the history of Azerbaijan. They legitimized the idea that the National Council is headed by Azerbaijan in paragraph 6 of the Declaration of Independence, confirming that the National Council was the first Azerbaijani Parliament, and that the Republic declared it a legitimate state of the people of Azerbaijan [4, p. 30].

On June 16, 1918, the National Council and the Government moved its operations center from Tbilisi to Ganja. Ganja experienced the first government crisis in the history of the Azerbaijan Democratic
Republic. At that time, there was a disagreement between the members of the National Council, Nuru Pasha, the commander of the Caucasus Islamic Army, who came to the aid of the genocide Azerbaijani people under the terms of the Batum Treaty (1918). The situation was exacerbated by the involvement of representatives of the bourgeoisie and its proprietors, fearing that the government would carry out revolutionary activities, and as a result, a conflict between Nuru Pasha and the National Council and the Government of Azerbaijan. There was the danger of losing the independence that was hardly earned. After the heated discussions held by the National Council on June 17 under the chairmanship of Rasulzadeh M.A., the crisis was overcome with great difficulty. Taking into account the real situation and specific historical conditions in the country, the National Council of Azerbaijan was forced to make two important decisions on June 17 in Ganja: temporarily suspended its activities; delegated all authority (both legislative and executive) to the new interim government, chaired by Fatali Khan Khoyski, before the Assembly of Enterprises convened [4, p. 30].

Thus, the first parliament of the Azerbaijan Democratic Republic, the National Council of Azerbaijan, began to take its first steps. During the first 20-day activity of the National Council of Azerbaijan, which lasted from May 27 to June 17, 1918, only 7 meetings were held and two important decisions were made at the first meeting: first - the Declaration of Independence of Azerbaijan and the Declaration of Independence; secondly, the first Azerbaijani government, headed by Fatali khan Hoyski, was formed, and after 1813, for the first time the independence of Azerbaijan began. Formation of Republican Structure in Part of Azerbaijan - Northern Azerbaijan [4, p. 32]

On September 17, 1918, after the liberation of Baku by the Islamic Caucasus Islamic Army, the government of F. Hoyski moved from Ganja to Baku. Baku is declared the capital of the Azerbaijan Democratic Republic. The National Council of Azerbaijan, which ceased its activity on June 17, 1918 in Ganja, resumed its work in Baku on November 16, $[1$, p. 6]. At the meeting of the National Council of Azerbaijan held on November 19, 1918, the important decisions of the history of the Azerbaijani parliament were made. At that time the Azerbaijan Democratic Republic, despite its extremely difficult and complex conditions, pursued an extremely democratic development. At the same meeting on November 19 it was noted that since the population of Azerbaijan is not only Azerbaijanis, the National Council of Azerbaijan should also represent non-nationalities, or rather all the peoples living on the territory of Azerbaijan. The Council of Azerbaijan should consist of 120 deputies with one delegate per 24 people of the country's population $(2$ million 750,000$)$. Of these, 80 were to represent the Turkish-Muslim population, 21 were 
Armenians, 10 were Russians, 1 was German, and 1 was Jewish. Even Georgians and Poles, who were not able to participate in the parliamentary elections due to their small numbers, decided to represent one member in Parliament [2, pp. 35-36].

The legal basis for the establishment of the ADR Parliament was defined by the Law on the Establishment of the Parliament of Azerbaijan at the November 20, 1918 meeting of the National Council of Azerbaijan. By law, elections to the unicameral parliament were held secretly. Leading figures of Azerbaijan, considering the sensitive attitude of the British to democracy, considered it appropriate to hold elections based on the principle of national representation, thus creating real conditions for the full restoration of interethnic peace in the republic. According to the law, at the end of 1917, 44 Turkish-Muslim deputies elected to the All-Russian Assembly of Enterprises were included in the newly created Parliament. The remaining 36 MPs and Muslims representing other nationalities had to be re-elected. The formation of the new Parliament was to be completed on December 3, 1918 [4, p. 36].

Apparently, despite the fact that only half a year has passed since the March 1918 massacre, 21 Armenian representatives were allowed to participate in the Azerbaijani Parliament. This historic step is a vivid demonstration of the deep respect for the democratic nature of the Azerbaijani people and human rights. This brilliant fact of parliamentary democracy in his address to the nation on November 29, 1918, calling for a new parliament, M.A. Rasulzadeh announced that he would own a new Parliamentary State, which would include representatives of minorities and all provinces of the country will organize and defend their interests $[4$, p. 36].

On December 3, 1918, the opening of the parliament was planned. Prime Minister F.KHoyski closely controls the conduct of elections in the area, and made efforts for the soonest establishment of parliament. The National Council of Azerbaijan also actively participated in the elections. On November 25, 1918, the National Council appealed to the Armenian and Russian national councils to send their representatives to the Parliament. Both councils declined to participate in parliament. The Armenian National Council has stated that it cannot represent the "interests" of all Armenians in parliament. The declaration of independence by the South Caucasus republics was generally welcomed by the negative opinion of the Russian National Council. Thus, the Russian National Council has not declared independence of any state in the Caucasus until the final decision of the All-Russian Assembly of Enterprises and the International Peace Conference and recognizes the South Caucasus as an integral part of the Russian state [6, p. 22].

The attitude of the British command in the creation of the ADR Parliament during this period was also sig- nificant. Under the terms of the peace treaty of Mudros in 1918, Baku had to be under the control of the British troops. On November 17, 1918, the British, led by Thomson, entered Baku and took over all administrative, judicial and executive structures. The attitude of the British command to the Democratic Republic of Azerbaijan was crucial. General Thomson officially announced that his final decision on all issues in the Caucasus would be made at the Paris Peace Conference. The opening of the parliament (Majilis-Mabusan), scheduled for December 3, 1918, was delayed by the English command's heavy pressure on the Azerbaijani government. In a letter to Major Rolanson, Chief of Staff of the United Kingdom S. Stokes, it was explicitly stated that the coalition government would not allow parliament to open parliament until it was recognized by the Allies [6, p. 22-23].

In spite of all these pressures, on December 7, 1918 at 13.00 there was a solemn opening of the Parliament of the Republic of Azerbaijan in the building of H.Z. Taghiev's girls' school (the building of the Fuzuli Manuscripts Institute). It was the Parliament formed throughout the Muslim East based on the most democratic principles of that time. According to the law of the National Council of Azerbaijan dated November 19, 1918, all the people living on the territory of the country were represented in the Parliament, even the small number of people who were not entitled to participate in the parliamentary elections. The seats in the Parliament of the Republic were distributed as follows: Turkish-Muslim population -80 , Armenians - 21, Russians - 10, Germans - 1, Jews - 1, Georgians - 1, Poles - 1, Baku Petroleum Trade Union and Trade Council -Industrial Union - 2 [4, p. 36].

Chairman of the National Council of Azerbaijan M.A.Rasulzadeh made a welcoming speech at the opening of the Parliament. Opening the first session of the Parliament, Chairman of the National Council and Musavat faction M.A. Rasulzadeh, in his speeches, spoke about the most important issues facing the Republic of Azerbaijan and emphasized that the main idea of the national interest was to realize and approve the ideas of freedom and independence. Expressing his unwavering belief that his people will never lose their loyalty to national ideals and will continue to move on the path of freedom and independence, M.A. Rasululzadeh said that the people of Azerbaijan wished freedom and democracy to all nations, including the people of Russia. The unity of the peoples of the South Caucasus, that is, their ability to live freely and independently, as hands-on neighbors, was one of the important issues addressed in this historic speech of Rasulzadeh and its solution was put in accordance with specific historical conditions. The main idea was that the nations living here should determine their own destiny. Recognition by the countries of the world community as a state and its internationalization as a full-fledged party was of 
great importance for the young Azerbaijan Republic. M.A. Rasulzadeh considered the unity of ideas and actions at the national level and the unanimity of activities as the main condition for the successful solution of this important issue. Alimardan bay Topchubashov, who is currently on a visit to the Musavat faction, was elected chairman of the parliament, and Hasan bey Agayev was his first deputy. Rahim bey Alaga oglu Vekilov has been approved by the Secretary of Parliament. Since A.Topchubashov is not in Azerbaijan, the activity of Parliament is headed by H.Agayev. At the first meeting of the Parliament, the resignation of Fatali Khan Khoyski's government was adopted and a decision was made to establish a new Government. The creation of the new Government was entrusted to Fatali khan Khoyskiy [4, p. 36].

On December 26, 1918, F.KHoyski presented his program in Parliament and presented the new Government for approval. Parliament adopted the program of Government and decided to trust the Government of F.KHoyski. On the same day, the new Government, headed by Fatali khan Khoyski, was announced. The government's program aimed to strengthen Azerbaijan's independence. The chairman of the Council of Ministers has shown here: "The independence of Azerbaijan is not just about creating a barrier between us and other countries. It is clear that the independent government of Azerbaijan will seek to establish a relationship with the nations. This communication should be produced first of all by neighboring countries, and generally those in the former Russia, especially Russia". Establishment of normal relations with the neighboring states, which strengthened their independence, recognition of Azerbaijan's independence and establishment of a national army is one of the first conditions for independence. Then, domestic politics ("We have never felt that Turkish Islamists have never considered themselves a homeland.. At the end of his speech, Fatali khan presented the new composition of the Council of Ministers to Parliament. After extensive discussion, the "Ittihad" faction remained neutral, and all the factions expressed their confidence in the government's program and composition [4, pp. 7-8]. On December 28, General Thomson, seeing the protection of the Democratic Republic of Azerbaijan by the people, recognized Fatali khan Hoyski as the only legitimate local authority in Azerbaijan. Thus, the relations between the Government of the Republic and the British military command began to soften. As a result, the Armenian military units in the city were disarmed and abolished.

From the very first day of its establishment, the Parliament of Azerbaijan has been building its activities on the basis of organizational principles specific to the democratic republics. It should be noted that although the law on the organization of the parliament envisages that the parliament has 120 members, there have never been many members of Parliament for var- ious reasons. By the end of 1919, only 96 MPs were represented in the Parliament of the II different party factions and groups. The ratios of political parties and groups in parliament were as follows: Musavat and one-sided faction (39 persons), ittihad (13), Socialist bloc (13), non-partisan (4), independents (3 persons), Armenian fraction (5 persons), Dashnaksutyun fraction (6 persons), minority fraction (4 persons) [2, p. 8].

Five cabinet chambers have been changed in the ADR Parliament. Three of them were headed by F. Khoyski, and two were headed by N. Yusifbeyov. All cabinets were created by a coalition of political parties and parties in parliament based on democratic principles. The government was responsible to the parliament. However, the existence of internal conflicts and divisions in the parliament made it difficult to pass laws and to govern the country. In addition, the fact that there are 11 factions and groups in the Parliament with less than 100 members, concentrating supreme power in the country, has also hampered the formation of an independent state under very complex domestic and international conditions. Separate factions and groups often outperformed their own faction and group interests over national interests. On the other hand, the inter-parliamentary demolition of the draft agrarian issue as a result of inter-factional struggle and its consequent rejection did not play a major role in the collapse and collapse of the People's Republic of Azerbaijan [4, p. 37].

Generally, the history of parliamentarism in the Azerbaijan Democratic Republic is divided into two periods: the first period - from May 27 to 19, 1918. During these six months, the first Azerbaijani Parliament, acting under the name of the National Council of Azerbaijan and consisting of 44 Muslim-Turkish MPs, has made important historical decisions. The first Parliament declared the independence of Azerbaijan on May 28, 1918, assumed control of the country and adopted the historic Declaration of Independence. The Declaration of Independence, proclaimed by the National Council of Azerbaijan at that time in a very complex and decisive moment, in the residence of the Caucasus monarch, is the historical document of the history of democratic and parliamentary traditions of Azerbaijan. During the National Council, only 10 sessions were held together with the constituent assembly of the Azerbaijani Parliament. The first meeting was held on May 27, 1918 in Tbilisi, and the last meeting was held on November 19, 1918 in Baku. The National Council of Azerbaijan was set up on May 27 and temporarily suspended its activities on June 17, not later than 6 months after the Assembly of Enterprises conferred the Interim Government's legislative and executive power to the Provisional Government. The National Council of Azerbaijan resumed its activities on November 16 after the move of the Government of the Democratic Republic to Baku on September 17, 1918. On November 19, the National 
Council of Azerbaijan passed a law on the calling of the Assembly of Enterprises - the Azerbaijani Parliament on December 3 of the same year - and ceased to exist. Thus, the Parliament of Azerbaijan operated in Tbilisi, Ganja and Baku during this period of its operation, or rather during the National Council [4, p. 37].

The second period in the parliamentarian history of the Azerbaijan Democratic Republic or the Baku period lasted from December 7, 1918 to April 27, 1920 - only 17 months. The first meeting was held on December 7, 1918, and the last meeting was held on April 27, 1920. During this period, there were only 145 sessions of the Parliament. At all these meetings, the Parliament of the Republic of Azerbaijan is committed to ensuring that the country's territorial integrity and independence are maintained, the most modern legal and democratic state where human rights and freedoms are fully respected, adhering to the principles set out in the Declaration of Independence. All these laws and resolutions were ultimately aimed at the formation of three branches of power - the legislative, executive and judicial authorities [4, p. 37-43]. At the same time the executive body - the Parliamentary body of Azerbaijan in the system of state-building through the adoption of government reports, which has a higher supervisory function on the Cabinet of Ministers. grandmother managed to create. Parliamentarianism, as a party to the separation of powers in state-building, determined the limits of their powers by the constitutional laws adopted at the outset. These laws include the rights and powers of the deputies, the procedure for their adoption, the activities of the commission and so on [6, p. 11].

\section{The Election Law of the ADR Parliament}

According to the Third Clause of the Electoral Regulations the number of the Azerbaijan members of the parliament was to be elected from the administrative- territorial entities in the following number [6, pp. 20-21].

Moslems-80 (Baku-5, Goychay-2, district of Javad-2, town of Guba-1, district of Lenkaran-2, district of Shamakhi-2, district of of Genje-2, district of Eresh-2, district of Javanshir-1, district of Zengezur-2, district of Gazakh-1, district of Jebrail-1, district of Nukha-2, district of Shusha-2, district of Zagatala- 2, from the Azerbaijan part of Irevan (Yerevan) gubernia-3, from the Azerbaijan part of Tiflis (Tbilisi) gubernia-1).

According to the law, the representatives of the Muslim population should be elected by secret ballot. At that time, five members of the city of Baku will be elected by Muslim members of the municipality of Baku, representatives from other cities, and national committees, as well as persons representing the district committees. It was considered possible that representatives of the municipality and non-national committees should be selected from the squad of community representatives to be formed by send- ing one representative from each community. The law provides for the appointment of representatives of the National Assembly to represent the places where the state of emergency applies. The organization and oversight of the election process are entrusted to city councilors, city councils or their deputies in districts, and minority nationals - chairmen of national minorities, who are asked to provide personally identifiable presentations and mandate $[1 ; 2$, p.15; 3, p. 82]. The law envisages the election of 36 out of 80 representatives to represent the country's Muslim population in the Parliament, from the capital city of Baku, parts of the Yerevan and Tiflis provinces to the territory of the Azerbaijan Democratic Republic, as well as other territorial units of the country $[2$, p. $15 ; 5,3$, p. 82].

The electoral law ensured the participation of all the Azerbaijan citizens with suffrage in the elections, irrespective of their political conviction, social status, religion and nationality. The firm political position of the members of the National Assembly led to the formation of a democratic parliament [6, p. 20].

The Declaration of Independence of May 28, 1918, declaring the establishment of the Azerbaijan Democratic Republic, provides information on the territory of the Azerbaijan Democratic Republic and indicated that Azerbaijan is a sovereign state, which covers the South-Eastern Transcaucasia. In addition, in November 1918 a special memorandum by Alimardan bay Topchubashov to the Antanta states representatives in Istanbul determined the territory of Azerbaijan. This issue was more broadly reflected in the requirements of the Azerbaijani Peace Mission at the Paris Peace Conference. According to this document, the regional distribution of the Azerbaijan Democratic Republic included the following areas: Baku gubernia (Baku district along with Baku district, Javad district, Goychay district, Shamakhi district, Guba district, Lankaran district); Elizavetpol (Ganja) gubernia (Elizavetpol, ie Ganja district, Javanshir district, Nukha district, Arash district, Shusha district, Garyagin, ie Jabrayil district, Zangezur district, Gazakh district); Iravan gubernia (Nakhchivan district, Sharur-Daralayaz district, Surmaili district, as well as New Beyazid district, part of Echmiadzin and Alexandropol district); Tbilisi gubernia (Borchali district, part of Tbilisi and Signakh district); Zagatala district; Dagestan Province (part of the area covering Kur and Samur, as well as part of the Kaitak-Tabasaran district, including the city of Derbend and its surroundings) $[4$, p. 11]

Thus, the Azerbaijan Parliament before the National Assembly consisted of the following number of parliamentarians elected on the system given below: a) 44 parliamentarians according to the lists of four Moslem political parties of the Transcaucasus elected to the Russian Assembly of Enterprises, who then became the members of the Transcaucasian Seim on the basis of the enlarged list and represented 
the Azerbaijan National Assembly; b) representatives elected by the authorized national organizations of the national minorities; c) representatives of self-administration of the towns of Azerbaijan and the National Committee of Moslems; d) representatives of industrialists and merchants [6, s. 21-22].

1917 Elections to the All-Russian Assembly of Enterprises. Muslim-Turkish members of the Transcaucasian Seim Muslim faction

On November 26-28, 1917 elections to the Russian Assembly of Enterprises were held in the Caucasus. As a result of the elections, the votes are distributed among the main parties in the Caucasus: Georgian Mensheviks - 661,934 votes, Musavat party - 645,816 votes, Dashnaksutyun party 558,400 votes, Muslim socialist bloc $-159,770$ votes, votes $-117,581$ votes. "Hummat" $-84,748$ votes and "Ittihad" - 66,504 votes [14, p. 4].

As a result, the National Committee of Muslims and the Musavat Party have joined the Russian Assembly of Enterprises - Hasan bey Agayev, Mammad Yusif Jafarov, Khosrov bey Sultanov, Mammad Amin Rasulzadeh, Ali Mardan bey Topchubashov, Nasib Bey Yusifbayov, Gazi Ahmad Mammadbayov; Muslim Socialist bloc - Ibrahim Heydarov, Alikhan Gantamirov, Aslan bey Safikurdski; Sultan Majid Ganizadeh and Jafar Akhundov from Hummat are elected. The Russian Assembly of Enterprises is composed of 34 deputies from the Transcaucasia, 12 of whom are Muslims [14, p. 4].

Deputies from Transcaucasia, which were opened on January 5, 1918, the same day by the Bolshevik government, were unable to go to Russia because the road was closed. Deputies elected from the Transcaucasia to the Russian Assembly of Enterprises decided on February 14, 1918 to establish the Transcaucasian Seim as the authority in the country. They decide to hold elections in Russia on Tuesday. The number of representatives of the Transcaucasian Seim increases according to the number of votes received by each party during the elections to the Russian Russian Assembly of Enterprises. The parties increase their representatives in exchange for the votes they receive in the elections to the Russian Parliament. 30 people from Musavat and Democratic neutralist groups, 7 from the Muslim Socialist bloc, 3 from the Ittihad party, and 4 from the Muslim Socialist-Democratic Menshovic Party 'Hummat' are in the Transcaucasian Seim. As a result, 44 Azerbaijani delegates from the Caucasus Seim participate in the formation of the Muslim majority of the Seim. These were the following [14, p. 4].

Musavat and democratic party groups: Mammad Yusif Jafarov, Alimardan bay Topchubashov, Mammad Amin Rasulzadeh, Nasib Bey Yusifbeyov, Hasan bey Agayev, Khosrov Pasha bey Sultanov, Mammad Hasan Hajinski, Mir Hidayat Seyidov, Ahmed Mohammadbeyov, Aslan bey Kardashov, Shafi bey Rustambayov, Javad Malik-Aslanov, Mustafa
Mahmudov, Mehdi bey Mehdi bey Hajibababeyov, Haji Molla Salim Akhundzadeh, Mehdi bey Hajinski, Hudadat bey Malik Aslanov, Ibrahim aga Vekilov, Hamid bey Shahtakhtinski, Rahim bey Vekilov, Alesgar bey Mahmudbekov, Yusif Efendi Efendizadeh, Mirza Jalal Yusifzadeh, Mammadrza aga Vekilov, Islam bey Kabulov.

From the Muslim socialist bloc: Ibrahim bey Heydarov, Alikhan Gantemir, Aslan bey Safikurdski, Ahmad Jovdet Pepinov, Bagir Rzayev, Camo Hajinski, Mohammad Maharramov.

Muslimity in Russia - from the Ittihad party: Sul$\tan$ Majid Ganiyev, Mir Yagub Mehdiyev, Heybatkulu Mammadbayov.

From the Muslim Social Democrat Menshevik Party: Jafar Akhundov, Ibrahim Abilov, Akbar aga Sheikhlislamov, Samad aga Agamalov.

It should be noted that after the opening of the ADR, these 44 members were directly and nonelected members of parliament.

The first independent meeting of the Transcaucasian Seim Muslim faction is held on March 16, 1918, chaired by M.A. Rasulzadeh. This meeting was attended by only 15 members [14, p. 5, 31].

The second meeting of the whole Muslim faction together with the delegation of the North Caucasus Mountains will be held on March 25 of the same year under the chairmanship of M.Y. Jafarov. Representatives of the North Caucasus Mountains - Zubair Temurkhanov, Magomed Gazi Dibirov, Gaidar Bammatov, Topa Chermoyev and Graf Lijanov (Representative of Ingushetia) attended the meeting along with 13 members of the faction. The main issue on the agenda was the unification of the North Caucasus with the Transcaucasia. This is reported by members of the North Caucasus delegation, Gaydar Bammatov and Count Lijanov. They say that Seim met with Georgian and Armenian representatives on the issue, that Georgians fully supported the issue, and the Armenians disagreed. Speaking on behalf of the Muslim faction, N. Yusifbeyov said that they totally liked the proposal and suggested to clarify the relationship between the Turks and Transcaucasian Turks. Topa, Chermoyev suggests combining the mountains with the Transcaucasia as a federative or confederate state. Rustambayov proposes to establish a commission consisting of mountaineers and Transcaucasian Turks to resolve this issue. The commission is represented by F. KHoyski, N. Yusifbeyov and A. Safikurdski, and from the mountains by G. Bammatov, T. Chermoyev and G. Dibirov [14, p. 5, 32-33].

M. Jafarov presided at the meetings of Seim Muslim faction from March 26 to April 3. The March 26 session of the Transcaucasian Seim, which returned from the peace conference in Trapezund, listened to a brief discussion of the Kars, Erdahan and Batumi issues of the Ottoman Empire to reach Brest-Litovsky. After a thorough discussion, the faction still retains its 
previous position and decides to send M.Y. Hajinski for this purpose [14, p. 5, 34].

At a meeting of the faction on March 31 in Baku, due to the massacre of the Dashnaks under the leadership of S. Shaumyan under the name of the Soviet forces, many members of the Muslim majority in Seim went to places, but representatives from each party had enough. The main issue on the agenda was to determine the attitude of the major Muslim parties on the issue of declaring war on Turkey on behalf of the Transcaucasian government. Not all parties of the Seim Muslim faction were unanimous about the issue. Representatives of the Hummat party express solidarity with the Georgian men and the representatives of the Muslim Socialist bloc against the continuation of the war and will speak independently at the Seim session on this issue [14, p. 5, 35].

The next meeting of the Muslim faction on April 1 opens with the announcement of a three-week emergency commission in connection with the declaration of war on Turkey and the postponement of Seim's meetings for two weeks. The session will discuss the tactics of the Seim Muslim faction and the determination of the line of action in relation to the situation. Mammadbeyov said that the government was disregarding the Muslims' interest in this action and canceled their role in the government and in Seim. That is why it is unbelievable and absurd for us to stay in Tbilisi and work with Georgians and Armenians in the future. In this regard, we need to leave the Caucasus Seim and their governments, and invite representatives from the North Caucasus to Dagestan, Chechnya and Ingushetia to discuss our future fate $[14$, p. 6, 36].

At the next meeting of the faction on April 3, a report by Khasmammedov, a member of the Transcaucasian peace delegation from Batumi, will be heard. The report says that the Turkish delegation will recognize the independence of the Transcaucasia when the Transcaucasian government agrees to join Kars, Erdogan and Batumi. The demand of the Turks was so serious that the Transcaucasian delegation had to make a major compromise. However, the delegation's response to the encrypted telegram to Tbilisi from B. Sereteli, N. Jordan and N. Ramishvili said that Batum's concession was an assassination, both in national and party terms. Other telegrams from Tbilisi are urged the delegation to leave Trapeze immediately. A. Chenkeli says that the delegation had to return in order to avoid contact with the Turks at the direction of the Transcaucasian government [14, p. 6, 37].

The meeting of the Muslim faction on April 9 opens with the report of M.A. Rasulzadeh on the results of the meeting of the factions, which are preparing the agenda of the next meeting of Seim. The first issue of the agenda is the declaration of independence of the Transcaucasia. second, the following draft resolution was approved for approval by Seym: By listening to the report of the peace delegation, it will be offered to continue negotiations that have been suspended [7, p. 43].

The session of the Muslim Seim faction on April 10 opens with a report by member of Seim M.N. Seyidov about the massacres committed against Azerbaijanis in Iravan province. He says in his report that the newly launched telegrams tell us that the massacres committed against Muslims in the Iravan province two months ago continue unabated and have become more aggravated in recent days. It is clear from the speaker that the operations carried out by the Armenians and the Armenian military against the Muslims had certain goals. Clear these areas for refugee Armenians and create new territories for Armenia. Other speakers did not touch this issue and tried to find ways to assist more than 80,000 Muslim refugees who had been sentenced to fate. They say the commission to help refugee Muslims is working very slowly. So far, even one million rubles allocated by the government for refugees have not been received. It is decided to ask the head of the newly created government, A. Chechenkel, to take the most urgent and urgent measures to protect the lives and property of Muslims in the Iravan province. The government should be questioned by the Saeima with the following requirements: (a) To charge the Interior Minister to send a special commission to assist Muslims; b) All Muslim refugees should be returned to their homes; (c) To charge the Ministry of Food to provide emergency food assistance; (d) To release the perverted military units organized by the Armenians; d) Provide additional resources for refugees by identifying their status and number" $[14$, p. 8, 44].

The Muslim faction of Seim first discusses the state structure in the Transcaucasia at a meeting of the Muslim faction on May 3. The issue of creating a federation or a confederate structure in the country has been the subject of lengthy debate and debate. As a result, it is decided that Georgia, Azerbaijan, and Armenia will defend the idea of establishing a confederation with the North Caucasus Mountains. Let Azerbaijan and the North Caucasus Mountains create a federation among themselves. Then the issue of anarchy in Azerbaijan is discussed. It has been reported that in the country, there are cases of murder, robbery, robbery, robbery and arbitrariness. Another reason for the aggravation of the situation in Azerbaijan is that the Bolsheviks of Baku are moving towards the country and the Bolshevik mood is growing. The meeting decided to instruct the Muslim ministers in the government to submit to the government detailed information on the intolerable situation in Azerbaijan [14, p. 9, 48].

The meetings of the Muslim faction held on May 6,13 and 16 were chaired by MYJafarov. At a meeting held by the Muslim Caucasian Central Muslim Council on May 6, the Caucasus Central Muslim Council and several representatives from different parts of the 
Caucasus, including representatives of the anarchy and the official representatives of the Seim Muslim faction in Baku and Yelizavetpol [14, p. 49-50].

On May 13, a meeting of the Transcaucasian Seim Muslim faction with more than a dozen representatives from different regions of the province of Elizavetpol, who want to meet with Turkish representatives in Batumi. The issue of whether these representatives are going to Batumi is first considered. After a detailed exchange of views, it becomes clear that there is no need for such representatives to go from every accident and location. There is no need for additional delegates to visit the Caucasus Muslims at a time when members of the Seim M.A. Rasululzadeh and M.Y. Hajinski are in talks with the officials of the Ottoman Empire in Batumi, and their attitudes are quite consistent. However, at the insistent request of the accident representatives, Mirza David, who wants to send representatives from Karabakh to get information about the talks in Batumi, is entrusted to the Minister of Public Education N. Yusifbeyov to negotiate with the relevant organizations to facilitate the departure of Batman to Batumi. The domestic and foreign political situation of Azerbaijan will be discussed at the meeting. Speakers say that the growing anarchy within the country, the distrust of neighboring nations, and the sending of aid by Turkey have already reached the point of destruction. This situation encourages us to take radical and realistic measures. First of all, send additional delegation to Batuma and even Istanbul to accelerate aid from Turkey; to appoint the Commissar-General to Azerbaijan with second-tier powers; third, to speed up the territorial division of the three Caucasian peoples. Seim members: M.Yafarov, N.Yusifbeyov and H.Hasmammadov are elected unanimously to send them to Batumi and Istanbul. It is decided that Khudadat bey Rafibeyov will be immediately appointed as CommissarGeneral of the Baku and Elizabethtown provinces, and all public and state organizations and officials will be subordinated to him. It is decided to hold a meeting of the faction on May 14 at 12 o'clock to determine the territory of the three Caucasian peoples. However, it seems that the meeting was not held that day because of the situation surrounding the Turkish army attack [14, p. 10, 51].

The Central Muslim Council of the Transcaucasian Central Council holds a meeting on May 16 in connection with the Turkish military attack and the new Turks' demand for the situation in the Transcaucasia and the restoration of Turkish military operations in Alexandrop. The member of the Seim N.Yusifbeyov informs that Georgian representatives of all levels feel the political situation very well. It seems from the talks that after the Batum adventure they will not be talking about a new adventure and a new war with the Turks. The Armenian representatives were quite different. Armenians, who have been crooked since the war between Russia and Turkey, are steadily leading their people to the abyss. The Armenians still intend to resist the weapons, even though they now know that resistance to the Turkish army will be a disaster for them. Their actions will, of course, cause a crisis in Seim's case, and as a logical consequence, Azerbaijan and Georgia should be ready to declare their independence [14, p. 11, 52].

In connection with the dramatic change in the political situation in the Transcaucasia, the morning of May 25, 1918, an extraordinary morning meeting of all Muslim factions of the Transcaucasian Seim under the chairmanship of Kh.Malik-Yeganov was held at the Janish Palace in Tiflis. According to reports from reliable sources, Georgians are holding secret talks with the Germans to declare their independence. Member of the Presidium of the Georgian National Council, G. Veshapeli, informed about this in his interview with the Secretary of the Transcaucasian Central Muslim Council, member of Seim Rahim Bey. From the discussion of the issue it is clear that the issue of separation of Georgians from the Transcaucasian Federation has been decided. Therefore, the Muslim faction of Seim should be prepared for such actions in advance. All Muslim factions agree with the principle that "if Georgia declares its independence, then Azerbaijan will declare its independence" $[14$, p. 11,54$]$.

At the final meeting of the Transcaucasian Seimah on May 25, the first step of our people towards parliament, the Transcaucasian Seim and its Muslim faction in Seim will be summarized with its release. Following a comprehensive discussion, the Muslim section of the Transcaucasia Seim made the following decision: "If Georgia declares its independence, then Azerbaijan must declare its independence" $[14$, s. 12,55$]$.

From May 27 to December 7, the second period of parliamentarism in Azerbaijan begins the activity of the National Council of Azerbaijan.

\section{The Regional election process}

At the third meeting of the parliament on December 15,1918 , a law on the organization of parliament was established by the National Assembly, when elected deputies were elected by regional National Councils from public institutions and districts. The procedure of approval of deputies' mandates has been the main topic of discussion for the third session of the Parliament. Some parliamentariansdid not consider the presence of ministers in Parliament until their mandates were approved, while others considered it possible to participate in voting before the election protocols were regulated [6, p. 35]. All this showed that the local elections were successful. At this session, following the report of the mandate commission, it was shown the adoption and approval of the mandate and protocols of the following representatives of the Parliament for the regions [2, p. 33]. 


\section{The elected members from Baku province:}

1. Guba resident Murtaza Akhundov, Guba resident Hamdulla Efendiev and Ali Bey Zizikski are required to confirm their mandate are valid and correct.

2. Bakhish bey Rustambayov and Rashid bey Akhundzadeh were elected by the Salyan city.

3. Sadikh Bey Aghabeyov and Haji Huseyn Efendiyev were elected by the city of Goychay. Confirmations are offered as they are valid and correct in law.

4. Shirvan Beyovski was elected a member of parliament for the city of Shirvan.

5. Sheikhalibeyov was elected by the National Assembly of Shamakhi. There has not been any news yet about the election of the Shamakhi district.

The elected members from Ganja province:

1. Abuzar bey Rzayev by Ganja, Haji Ali Gasim oglu and Haji Molla Ahmed Nuruzadeh by Ganja district, election protocols are drawn up according to the law and their approval is submitted to parliament.

2. Haji Karim Saniyev was elected from the Gazakh district, and his confirmation is provided that his mandate are in line with the law.

3. Bahram bey Vazirov was elected from the Jabrayil district. Confirmation is offered because its power of attorney is law.

4. By the city of Shusha were elected Kara Bey Aliverdiyev from Aghdam to the National Assembly. In addition, it is the fact that the power of attorney and the protocol were signed by the district clerk, a material presentation is offered in this regard. It is only temporary, and papers are acceptable.

5. Abdulla bey Efendiyev by the Sheki City Administration and Karib Karimov was elected by the district. Confirmations are offered because their mandates are correct.

6. Ashraf Tagiyev from Aghdash elected by Eresh district and Jamil Suleymanov from the district, has no mandate and the mandate committee recommends that they refuse to submit their mandate and legal protocols before they submit the protocol.

7. Bayram Niyazi Kichikkhanov's powers have been signed by the governor of Zagatala and have no election protocol by the National Assembly. Therefore, the power of attorney offers to submit an election protocol.

At the same meeting confirmation of the representatives proposed by the Mandate commission for membership in Parliament is as follows [2, p. 37]:

- Representative from Guba district - Zizikski and Hamdulla Efendi's mandates are confirmed as legitimate.

- The mandates of the representatives from Goychay district - Sadig bey Agabeyov and Haji Huseyn Efendiyev are considered legitimate.

- Sheikhalibeyov's mandate from Shirvan district is confirmed as legitimate.

- Haji Kerim Saniyev's election from Gazakh district is considered legitimate.
- The representation of Bahram bey Vezirov from Jabrayil district is considered correct and his representation is confirmed.

- The mandates of Abdulla bey Efendiyev and Kara bey Kerimov from Sheki district are confirmed by the law.

At the meeting of the Parliament No.5 of December 26, 1918, the issue of representation of Ahmad bey Agayev by Zangazur district is discussed. Thus, it is decided to submit the Telegraph sending Parliamentary Presidium to the Mandate Commission [2, p. 53]. In addition, at a meeting of the Parliament No. 21 of March 10, 1919, it was decided to submit the mandate of Jamil bey Sultanov, elected by the parliament to Zangazur [2, p. 158].

On November 24, 1918 the telegram sent to the chairman of the Council of Ministers, said that elections were held in the district of Javad. After counting the votes with eight extra votes Bakhish bey Rustambeyov from the district of Salyan and Rashid bey Akhundzadeh from the district of Javad were elected to the parliament. The record on the election was compiled in two copies and one of them was sent to the chairman of the Council of Ministers. Information on elections held in other districts was also sent to the government [6, s. 31].

According to the report of the mandate comission of the Parliament, dated January 16, 1919, the mandates of Zeynal bey Vezirov and Ahmed bey Agayev, elected from the Shusha district, offers their approval. Ahmed bey refused, Mr. Vazirov remains. It is also planned to approve the mandate of Bahram Niyazi Kichikkhanov and Kabudov elected from the Zagatala district and the decision will be taken by a majority of votes [7, p. 256].

One of the issues discussed at the Parliamentary Meeting No. 11 of January 28, 1919 is the fact that Haji Karim Saniyev, the representative of the Gazakh district, was not elected in parliament in a telegram signed by several members of the Gazakh National Committee. In the telegram, Haji Karim Saniyev is asked to exclude the parliament and propose a new constitution for the Gazakh district. This proposal submitted to the Parliament is forwarded to the Mandate Commission for discussion [2, p. 88; 7, pp. 290-291]. This issue was again raised at the parliament's meeting on March 6, 1919, and the issue was referred to the mandate commission by a complaint from Gazakh district about the wrong election of Haji Karim Saniyev [2, p. 148; 7, p. 508].

At the Parliamentary Meeting No.10 of February 5, 1919, Aghdash, represented by Eresh as a member of parliament, was asked to remove Ashraf Tagiyev from the fact that he had not been in parliament for 2 months and is requested by the fraction to send a new one to replace the deputy [2, p. 100; 7, p. 341].

At the Parliamentary Meeting No.18 of February 18, 1919, Javanshir Representative Dr. Jamil bey Lan- 
baranski refuses to become a member of Parliament with his health and general supervision $[2$, p. 125; 7, p. 433]. At the meeting, new list of candidates nominated by Musavat and the National Committee on Replacing Exiles: Mustafa Vakilov, Aga Amirov, Yusifali Aliyev, Sheikhzamanov, Mohammad Ali Rasulzadeh, Behbudkhan Javanshir, Bahram bey Akhundov, Abdulali bey Amircanov. Despite the controversy surrounding the proposal, it is accepted by a majority of votes [2, p. 125-1289; 7, p. 434-441].

At the meeting of Parliament No. 24 of March 17,1919 , the Chairman of the mandate commission, Shafi Bey Rustambeyli, reported that last time the representatives of the Armed Forces were returned because their election protocols were not correct. Two people, Mukhtar Efendizadeh and Ashraf bey Tagiyev, have been selected from the crash. He notes that the mandate commission recommends that parliament consider the representatives of the (Arash) district because it looks at the election protocols. He said that Ahmed bey Agayev and Alekber bey Hasmammadov were elected members of parliament from the Zangazur district. Their election protocols were not correct. First, a copy (commission) of their election protocols was sent. In addition, it was not signed by members of the national committee and secretary. He added that Jamil bey Sultanov was selected and sent from Zangazur. Since the mandate of Jamil bey Sultanov are fair and the electoral law suggests the admission of the commission to the parliament, it is decided to send a second representative from Zangazur [2, p.168; 7, p. 548-549].

At the same meeting, Shirin bey Safaralibeyov was elected from Shamakhi district, but his mandate were returned and his proposal was submitted to another parliament. In addition, at the meeting, the mandate of Mukhtar Efendiizadeh and Ashraf Tagizadeh, who were nominated as members of the Armed disaster, were confirmed. The trust of Jamil bey Sultanov from Zangazur district is confirmed and it is necessary to submit another representative [2, p. 168; 7, p. 550].

At the meeting of the Parliament No. 27 of April 7, 1919, Goychay city was informed that other papers were included in the case of Rza bey Aghasibeyov joining the parliament. Thus, Rza bey Agasybeyov is elected a member of parliament by the city of Goychay $[2$, p. $189 ; 7$, p. 622].

At the meeting of Parliament No. 70 dated 01 September 1919, the power of attorney from the Shamakhi municipality was transferred to the power of attorney for the election of Iskander bey Akhundov as a member of parliament from the Shamakhi district. At that meeting, the mandate commission's proposal to join Iskender bey Akhundov was accepted by a majority of votes [9, p. 38].

At the meeting of Parliament No.85 of October 18, 1919, documents concerning the seizure of Samad bey Mehmandarov from the Lankaran district are discussed and sent to the mandate commission [9, p. 115]. At the meeting of Parliament No. 96 dated November 10, 1919, the validity of the election in Lankaran regarding Mehmandarov's parliamentary membership is put to vote. The decision is adopted by a majority of votes, and Mehmandarov becomes a member of parliament [9, p. 189].

At the meeting of the Parliament No. 96 of November 10, 1919, with the participation of the Zangazur National Committee and district representatives, it was mentioned that Jalil bey Sultanov and Mirza Sadig Akhundzadeh were elected, and the mandate commission suggests their membership. The decision is adopted by a majority of votes, and both delegates are members of parliament from the Zangazur district [9, p. 190-195].

At the meeting of Parliament No. 106 of December 11, 1919, it was decided to send the documents of Gulamhuseyn bey Kazimbayov, elected from Lankaran district, to the commission [7, p. 146, 9, p. 247]. In addition, the mandate for the election of Samad Karbalai Hasan, a member of Ganja at the Parliamentary Assembly No.126 of 19 February 1920, is submitted to the mandate commission [7, p. 130, 9, p. 317].

At the Parliamentary Meeting No.110 of December 25, 1919, the mandate, introduced by Baba bey Gabulov as a member of parliament in place of the former representative of Zagatala, was forwarded to the mandate commission [9, p. 274].

Conclusions. The National Assembly's Law on Parliamentary Elections was published in newspapers, and the form of protocols were sent to the governor and chiefs of municipalities. "The Law on the Institution of the Parliament of Azerbaijan", which defines the legal basis for the establishment of the Azerbaijani parliament, regulates all procedural rules, and provided the rules of election and appointment of the parliamentarians. The law regulated all the procedures and secret balloting, and determined that 24000 people should elect one parliamentarian. The law laid the responsibility for holding elections and for counting their results on the chairpersons of municipalities in the towns, and on the judges, or their deputies in districts. The law also regulated the rules when any of the 44 former parliamentarians (who were the members of the National Assembly) resigned, or left the parliament because of some reason (for instance, death), or how they were substituted by the members of fractions which replaced them [6, p. 33-34]

Proceeding from the traditions of democracy in the Parliament the members of the parliament demanded that the Mandate Commission should proceed from the principle of the rule of law and obey the law adopted by the National Assembly on the legislative body, demanded records of elections and mandates for each elected person from the provinces [6, p. 34].

Conclusively, the ADR parliament, created in a complicated historical period, played an impor- 
tant role in the formation of the legislative power in Azerbaijan. Parliament is known as the center of political thinking reflecting the national political spirit, national mentality, domestic and foreign policy of Azerbaijan [10, p. 225]. The Parliament's progress on the path of state building reached a stage where it acted not only as legislative but also the executive organ. In other words, it was successful in performing supervisory functions over the Cabinet of Ministers, hearing reports of the government and thus, made a start on the Azerbaijani Parliamentarianism traditions without the system of state building. Combining democratic elements of the progressive Parliamentarianism, the Parliament of the ADR managed to meet interests of the nation and protect the national sovereignty [6, p. 11].

\section{REFERENCES:}

1. Baxışov Vüsal. Azərbaycan Cümhuriyyəti Məclisi-Məbusanında Nuxa qəzasını təmsil etmiş Şəxslər. Әdalət. 2018. 7 iyun. № 101. S. 7.

2. Azərbaycan Xalq Cümhuriyyəti (1918-1920), Parlament (Stenoqrafik hesabatlar). I cild. Bakı, "Azərbaycan" nəşriyyatı, 1998. $427 \mathrm{~s}$.

3. Zaqafqaziya Seyminin müsəlman fraksiyası və Azərbaycan Milli Şurasi iclaslarının protokolları. 1918-ci il, Bakı, "Adiloğlu" nəşriyyatı, 2006. 216 səh.

4. Azərbaycan Xalq Cümhuriyyəti Ensiklopediyası. İki cilddə. I cild, Bakı, "Lider" nəşriyyatı, 2004. $471 \mathrm{~s}$.

5. Sadayoğlu Pərviz. Azərbaycan Xalq Cümhuriyyəti - Şərqdə ilk parlamentli respublika/ "Yeni Azərbaycan" qəzeti, 26 may 2009-cu il. № 96.

6. Әsədov Oqtay, Cəbrayılov Rafael. Azərbaycan Respublikasının Parlamenti. Bakı, 2008. $519 \mathrm{s.}$

7. "Azərbaycan"qəzetində parlament hesabatları və şərhləri (araşdıı toplayanı, ərəb əlifbasından latın əlifbasına çevirəni, ön sözün müəllifi, lüğətin tərtibçisi Şirməmməd Hüseynov): 3 cilddə, Ill c., Bakı : Qanun, 2016. 551 s.

8. "Azərbaycan"qəzetində parlament hesabatları və şərhləri (araşdırıb toplayanı, ərəb əlifbasından latın əlifbasına çevirəni, ön sözün müəllifi, lüğətin tərtibçisi Şirməmməd Hüseynov): 3 cilddə, I c., Bakı : Qanun, 2016. 655 s.

9. Azərbaycan Xalq Cümhuriyyəti (1918-1920). Parlament (stenoqrafik hesabatlar): 2 cilddə, Il c., Bakı, 1998.435s.

10. Abbasova Gülarə. AXC dövründə parlamentin fəaliyyəti və hökumətin təşkili. Tarix və onun problemləri. 2012. № 3. S. 223-227.

11. Solmaz Tohidi - Rüstəmova. Azərbaycan parlamenti necə yarandı? Xalq qəzeti. 2019. 25 may. № 114. S. 6.

12. Məmməd $\partial \min$ Rəsulzadə. Әsərləri (araşdırıb toplayanı, ərəb əlifbasından latın qrafıkasına çevirəni, ön sözün müəllifı, lüğətin tərtibçisi Şirməmməd Hüseynov), IV cild. Bakı : "Qanun ”, 2013. 456 səh.

13. Azərbaycan tarixi:7 cilddə,V c. Bakı : Elm, 2007. $584 \mathrm{~s}$.

14. Habil Həmidov. Azərbaycan Xalq Cümhuriyyətinin formalaşması prosesinə ictimai-siyasi baxış. Xalq qəzeti. 2018. 3 iyun. № 124. S. 5.

15. Sevda Süleymanova. İlk demokratik Azərbaycan parlamentinin formalaşması. Azərbaycan Respublikası Prezidenti yanında Dövlət idarəçilik Akademiyası, Azərbaycan Xalq Cümhuriyyətinin 95 illiyinə həsr edilmiş Respublika elmi konfransının materialları, 22 may 2013-cü il, Bakı "Elm və Təhsil", 2014. S. 37-42. 